\title{
What Does WTO Membership Kindle in Transition Economies?: An Empirical Investigation
}

\author{
Nauro F. Campos \\ University of Newcastle, CEPR (London), \\ Davidson Institute at the University of Michigan
}

\begin{abstract}
Many believe that an important benefit from membership in international organizations is the lessening of political constraints to domestic reforms which would, ultimately, generate greater trade openness, FDI inflows and economic growth. These ideas have received limited empirical testing. This paper tries to fill this gap using panel data for 25 transition economies during the 1990s. We find that WTO membership had little impact on trade openness, FDI and growth, but a positive effect on domestic reform (external liberalization). Unfortunately, we can not yet distinguish whether this effect is real or due to the poor measurement of reform.
\end{abstract}

- JEL Classifications: F2, O11, P33

- Key words: WTO, Economic reform, Transition economies

\section{Introduction}

There is a large theoretical literature which argues that membership in international organizations (such as the World Trade Organisation, WTO, and the European Union, EU) lessens political constraints to the domestic reform process because it helps governments commit to welfare increasing policies that would not

\footnotetext{
*Corresponding address: Nauro F. Campos, Department of Economics, University of Newcastle, Newcastle-upon-Tyne NE1 7RU, United Kingdom. Tel: +44 191222 6861, Fax: +44 191222 6548, Email: n.f.campos@ncl.ac.uk

(C2004-Center for International Economics, Sejong Institution, All Rights Reserved.
} 
otherwise be credible to domestic agents. ${ }^{1}$ The expectation is that the lessening of those political constraints would trigger reform which by its turn would generate greater trade openness, FDI inflows and, ultimately, economic growth. These ideas have received very limited empirical testing. This paper tries to fill this gap by concentrating on the experience of the Central European and former Soviet Union countries during their transition from centrally planned to market based economy.

Following the break-up of the Soviet Union and the collapse of the Council for Mutual Economic Assistance (CMEA), it became clear that membership in international organizations was instrumental to the re-integration of the former communist countries in the international economy. A few economies had already joined GATT, ${ }^{2}$ while others went through WTO accession processes. This provides for a quasi-experimental setting to investigate the economic effects of WTO membership because there is, across transition economies, a mix of WTO members and non-members and members have joined at rather different dates (Table 1). ${ }^{3}$

Another motivation for this research is a potential comparison between WTO and EU membership. ${ }^{4}$ It has been pointed that one factor explaining the relative success of the Central European countries vis-à-vis those from the former Soviet Union is that most of the former will become full members of the EU. The rationale is that the expectation of joining the EU has served to relax political constraints to domestic economic reform processes (Berglof and Roland, 1997). Further, whether or not the WTO-anchor to reform can substitute for the EUanchor is an issue of great importance, especially for those countries for which EU

\footnotetext{
${ }^{1}$ See, for example, Berglof and Roland (1997) and Staiger and Tabellini (1989, 1999).

${ }^{2}$ The World Trade Organization was established on January 1, 1995, as the successor to the General Agreement on Tariffs and Trade (GATT). Among transition economies, the countries that were GATT members are (accession date in parenthesis) Czech Republic (1993), Hungary (1973), Poland (1967), Romania (1971), Slovakia (1993) and Slovenia (1994).

${ }^{3}$ This issue is particularly important in light of a recent study (Rose, forthcoming) which finds that, for very large samples of developing and developed countries, WTO membership does not seem to lead to a more liberal trade policy (using 68 different measures of trade policy and liberalization).

${ }^{4}$ Although the coverage of the WTO agreements is narrower than in the EU case, enforcement seems more effective in the WTO: Berglof and Roland warn that "the existing (enforcement) powers of the EU are weak, and these powers are likely to deteriorate rather than improve with enlargement" (1997, p. 2). See also Holmes (2001), Holmes and Iacovone (2001) and Michalopoulos (1998).
} 
Table 1. Transition Economies: WTO Members (with dates of membership) and Observers

\author{
Members
}

Albania

Bulgaria

Croatia

8 September 2000

Latvia

10 February 1999

Czech

1 December 1996

Lithuania

31 May 2001

Republic

30 November 2000

Moldova

26 July 2001

Estonia

1 January 1995

Poland

1 July 1995

Georgia

13 November 1999

Romania

1 January 1995

Hungary

14 June 2000

Slovak Rep

1 January 1995

Kyrgyz Republic

1 January 1995

Slovenia

30 July 1995

Observers

\begin{tabular}{llll} 
Armenia & Azerbaijan & Belarus & Bosnia and Herzegovina \\
FYR Macedonia & Kazakstan & Russian Federation & Tajikistan \\
Ukraine & Uzbekistan & FR Yugoslavia & \\
\hline
\end{tabular}

Source: http://www.wto.org

accession is not a feasible medium-term objective. ${ }^{5}$

Using panel data for 25 transition economies between 1990 and 1998, we find that WTO membership had little impact on trade openness, FDI and growth, but a positive effect on domestic reform (external liberalization). Unfortunately, we can not yet distinguish whether this effect is real or due to the poor measurement of reform.

The paper is structured as follows. Section 2 briefly discusses the main economic events of the transition. Section 3 uses newly available quality data to examine what happened to trade openness during the transition and also discusses the dynamics of external liberalization (reform) efforts. Section 4 has the empirical results. Section 5 concludes and puts forward some suggestions for future research.

\footnotetext{
${ }^{5}$ There is at least one more noteworthy advantages of studying WTO vis-à-vis EU membership: the former refers to actual membership, while the latter refers to expected membership. It is difficult to identify and measure "the prospect of EU membership" and, making matters worse, it is conceivable that "the prospect of EU membership" has changed over time. For the sake of illustration: in early 1997, Latvia and Lithuania had few reasons to expect to join the EU as early as, say, Poland or Hungary.
} 


\section{The First Decade of Transition}

The objective of this section is to briefly describe the transition experience by presenting a set of stylized facts that summarizes the key developments in the first ten years or so of the transition from centrally planed to market based economy.

The legacy of socialism is crucial to understand the transition. What were the economic characteristics of the socialist system $?^{6}$ Ericsson (1991) summarizes the Soviet-type economy in the following nine main characteristics: (1) hierarchical structure of authority, (2) centralized economic planning, (3) commitment to maximal resource utilization, (4) formal rationing through administered allocation in physical terms of producers goods and services, (5) rigid price control, (6) lack of true money, (7) lack of legal alternatives to assigned economic relationships, (8) arbitrary control by superiors of the norms and indices of plan assignments, performance evaluation and rewards, and (9) incentives geared towards meeting plan targets.

Economic growth was an imperative of the socialist system. The pattern of economic growth pre-1989 was based on extensive growth, it favoured accumulation instead of technological and organizational changes (Ofer, 1987). There seems to be consensus that the extensive growth strategy, achieved by rapid industrialization, worked rather well until the 1960s. With the first signs of growth slowdown, it became clear that the technological gap with the West was opening up. In 1973, the first oil shock gave the Eastern bloc some room to breathe, as the Soviet Union was a major producer. However, western economies responded to the two oil shocks with a boom in energy-saving computer-based technological innovations. The emergence and rapid diffusion of these technologies is often taken as a major contributor to the end of socialism (Stiglitz, 1994). The end of socialism is the beginning of the transition.

Campos and Coricelli (2002) put forward the following set of stylized facts of the first decade of the transition: (1) Output fell: Output fell in all countries of the former eastern Bloc, in stark contrast with development in China and Vietnam (where growth has been fast and sustained). The exact magnitude of the fall is a matter of controversy, inter alia, because of the sizeable informal sectors that emerged. (2) Capital shrank: Physical capital stocks reduced dramatically during the transition, although the expectation is that efficiency has increased. (3) Labour

${ }^{6}$ Kornai (1992) provides an authoritative discussion of the main features of the socialist system. 
moved: Labour moved in all senses, but the most obvious one: measures of geographical mobility are very low. Yet, there were large changes in labour markets status, sectors, and occupations. (4) Trade reoriented: CMEA trade collapsed and was re-directed to industrial countries in a very short period of time. (5) The structure changed: The share of value added by industry in GDP declined rapidly. In the CEEB case, this was due almost exclusively to the increase of the services share. In the case of the CIS, the reasons for the slower decline are less clear-cut. (6) Institutions collapsed: The collapse of communism created an enormous institutional vacuum. Although efforts to understand and measure it are just starting now, its effects are sizeable and omnipresent. And (7) transition costs: One of the surprises of the transition was the appearance of unexpected costs. The rise of unemployment and income inequality was expected. The rise in mortality rates and the decline in school enrolment rates were not expected.

This section has set the background for the rest of the paper. We have briefly noted what happened in the first ten years of the transition in Central and Eastern Europe. We stress that output fell, capital shrank, labour moved and that the structure of these economies has changed substantially. We also argue that institutions collapsed and that there were large, unexpected, social costs associated with the transition. Now it is time to turn to what happened to trade openness and external reform, which are the two areas in which the effects of WTO membership are expected to be more clearly seen.

\section{Trade Openness and Economic Reform in Transition}

The objective of this section is to present empirical evidence concerning the two related areas in which the impact of the WTO Agreement is expected to be stronger, namely, trade openness and trade liberalization.

One issue to investigate is whether or not the output fall affected foreign trade, and if so, whether trade exhibits a similar dynamics. The proposition about the reverse link that the collapse of CMEA deepened the output fall and that successful trade performance has helped the recovery reinforces the importance of trade dynamics in transition. Another worthwhile question originates from the expectation that market forces would change trade patterns of transition countries by reorienting trade towards western markets. ${ }^{7}$ After a decade of transition, one

\footnotetext{
${ }^{7}$ See Baldwin (1994), Kaminski, Wang and Winters (1996) and Maurel and Cheikbossian (1997).
} 
should ask whether the trade data indicate that such redirection has indeed taken place. Another important question we ask is whether or not these economies become more open to trade during the transition from plan to market. The jury seems still out on this because the break-ups of the Soviet Union and Yugoslavia may mask actual developments in trade openness because what was inter-republic trade before 1989 is counted as international trade after 1991. A closer (re-) examination of such issues is warranted.

In this section, the focus is on three foreign trade dimensions: trade volumes, trade patterns and trade openness (trade-to-GDP ratio). The crucial difficulty relates to data. Trade data for the former Soviet Union (FSU) countries (Baltic and CIS) are taken from Belkindas and Ivanova (1995) for the years 1990-1994 and from the IMF Direction of Trade Statistics (DOTS) for the years 1994-1998. The inclusion of year 1994 in both series serves to evaluate the costs of using different non-overlapping data sources. For the non-FSU transition economies data are taken from the IMF DOTS.

These data seem to support the proposition that the level of foreign trade in transition countries has followed a decline and (partial) recovery pattern. Averages of export indexes indicate an initial decline and partial recovery in foreign trade for both CEEB and CIS countries. CEEB exports declined until 1993 reaching 62 percent of their 1990 level to then rise to 71 percent of their 1990 level by 1998 . CIS exports reached their lowest level a year later, in 1994, but the drop in CIS trade was much more pronounced. Although exports from the CIS countries did show clear signs of recovery since, exports declined again in 1998, this time due to the crisis in Russia. In 1998 CIS exports were about 30 percent higher than in the trough year (1994) but still represented only 15 percent of the 1990 level of exports.

Regarding trade redirection, Figure 1 shows that the share of industrial countries has increased greatly in the exports of CEEB and CIS, as well as in all the subgroups of transition economies. The sample was divided in five groups for exposition purposes. The transition countries in ASIA are Armenia, Azerbaijan, Georgia, Kazakhstan, Kyrgyztan, Tajikistan, Turkmenistan and Uzbekistan. The BALKAN countries are Albania, Bulgaria, Croatia, Macedonia, Moldova and Romania. The BALTIC countries are Estonia, Latvia and Lithuania. The group called BUR comprises Belarus, Ukraine and Russia. The VISEGRAD countries are the Czech Republic, Hungary, Poland, Slovakia and Slovenia. CEEB stands for Central and Eastern European and Baltic countries and represents the sum of 
the BALTIC, BALKAN and VISEGRAD sub-groups. The Commonwealth of Independent States (CIS) encompasses BUR and ASIA.

The percentage of exports to industrial countries from the CEEB started out twice as high as that share from CIS countries and ends the period three times as high. The share of VISEGRAD trade to industrial countries has always been the highest, while the shares from the ASIA and BUR groups have been consistently the lowest (indeed almost a third of the share of VISEGRAD throughout this period). Despite relatively high initial shares, adjustment was rapid: the share of exports to industrial countries in total exports rise from about 55 percent to more than 70 percent for the VISEGRAD group, from 45 to 55 percent for the Balkan countries, and from roughly 15 to 25 percent for BUR and Asia economies. Keeping in mind the collapse of the Soviet Union and its implications for interindustry trade, the speed of re-orientation of trade in the Baltics is remarkable. The percentage of Baltic exports to industrial countries grew from less then 5 percent in 1991 to more than 50 percent in 1998. This compares very favourably with increases in the shares of the ASIA and BUR groups from about 7 percent to about 24 percent and from about 14 percent (1992) to about 26 percent, respectively, over the same period.

What dynamics one should expect for trade openness during transition? It was often claimed that central planning created excessively integrated economies and, if this assessment is correct, the collapse of CMEA would lead to somewhat less open economies. A closer look at the evolution of openness (measured combining the two data sets discussed above) supports two observations. First, there was a

Figure 1. Share of industrial countries (\% of total exports)

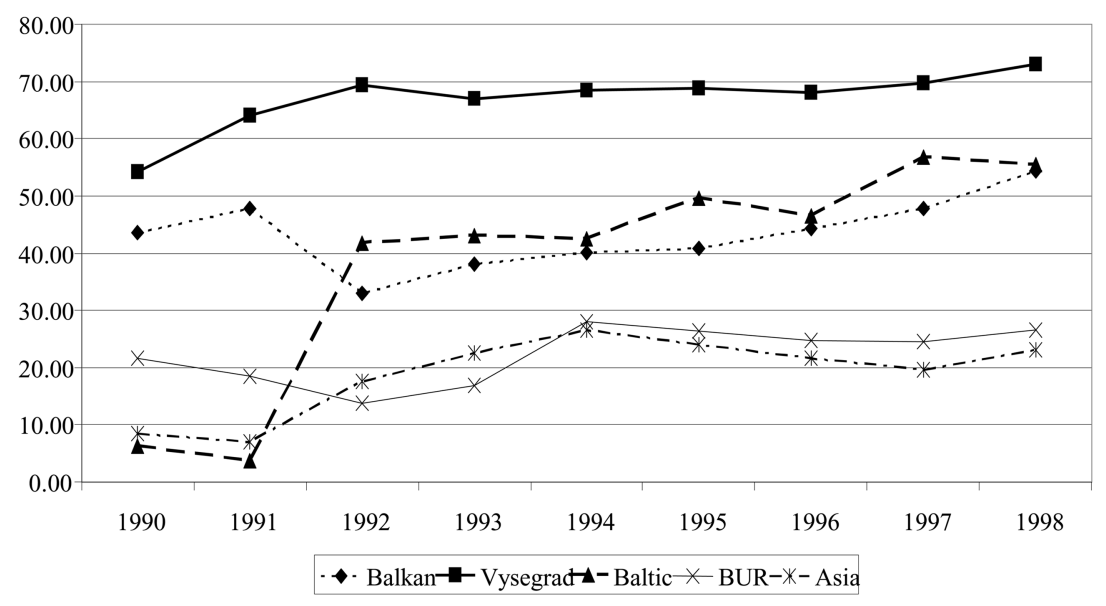


relatively turbulent period characterized by a strong decline of the ratio of trade to GDP in the case of CIS in 1991 followed by a sharp rise for both CEEB and CIS in 1992. Second, the trade-to-GDP ratio was relatively stable over 1992-1997, although slowly declining in the case of CIS. In 1997, both CEEB and CIS countries are not less but rather more open economies than at the start of transition. 8 This is clearly so for Balkan, Visegrad and Baltic countries. ${ }^{8}$ The BUR and Asia countries seem to have the same trade-to-GDP ratios in 1998 as they had at the beginning of transition.

It is important to call attention to the fact that this analysis uses a measure of openness (trade-to-GDP ratio) constructed from combining data from Belkindas and Ivanova (1995) and from the IMF Direction of Trade Statistics. One serious drawback is that the underlying figures are not purchasing power parity adjusted. The Penn World Tables (PWT) has been the source for such data in the empirical literature. As its latest version (PWT 6.1) is just available (Heston, Summers and Aten, 2002), a worthwhile question is: do the conclusions above change with this recently available, better quality, data?

Figure 2 plots the PPP-adjusted trade-to-GDP ratio from the latest PWT for the Central European and CIS countries separately. At a more aggregate level, the same tendency identified above seems to have prevailed: the openness of transition economies has increased since 1990. Trade openness, irrespective of the data series used, seems to have increased rapidly in the beginning of the transition but peaking early on (about 1992 or 1993). Yet the PWT data adds an interesting piece of information. The figure shows that until 1994 the behaviour of trade openness in the two groups is very similar, yet the extent of their divergence after 1994 is impressive. Trade openness in CEEC countries continue to increase for the next three years, surpassing the 1992 level already by 1996. In stark contrast, after 1994, trade openness in the CIS countries declines almost continuously reaching an all-time low (in the available data) in 1998.

Let us turn to external reform. One important debate in the literature is whether initial conditions or economic reform policies have played the crucial role during the transition process. One fundamental problem in gauging the role of reform is the difficulty in obtaining reliable measures. The available ones are not detailed enough and more often than not are based on Western experts' judgement, when

\footnotetext{
${ }^{8}$ Havrylyshyn and Al-Atrash (1998) empirically address the question of how trade-to-GDP ratios of transition economies in 1995 compare to those of "more established market economies." They conclude that transition economies were as open as the "benchmark" market economies.
} 
Figure 2. Openness in Transition(PWT 6.1 data)

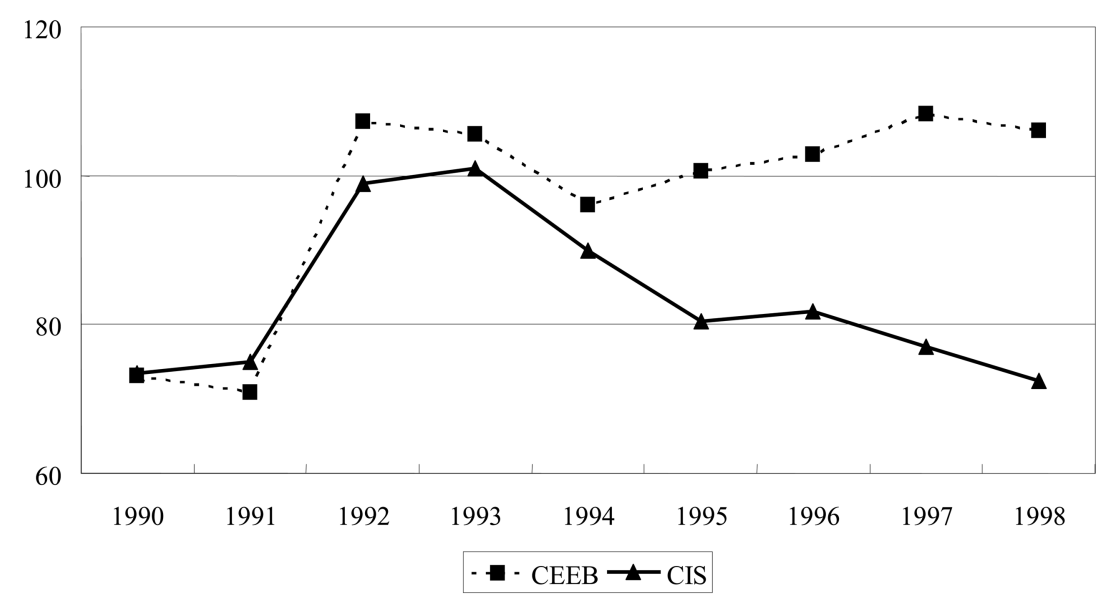

they need not be. ${ }^{9}$ The measure of economic reform most widely used in the transition literature is the De Melo, Cevdet, Gelb and Tenev (1997) external liberalization index. These liberalization indexes are calculated for each country and each year. They range from 0 to 1 where 0 represents unreformed and 1 represents a basically-reformed country. The index of external liberalization reflects "the liberalization of the foreign trade regime, including the elimination of export controls and taxes and substitution of low to moderate import duties for import quotas and high import tariffs" (1997, p. 6).

According to these data, domestic reform efforts (that is, the external liberalization index) have progressed much faster in Central and Eastern European than in the former Soviet Union countries. It is surprising to learn how difficult it seems to try to distinguish the ASIA from the BUR countries as in both groups reforms seem to have taken off too timidly. Also of interest is that, according to these indexes, the reform effort in the Baltic countries has been much more modest than in the Visegrad and BALKAN countries.

Finally, WTO membership is also expected to have deep and broad impacts on inflows of foreign direct investment. Since the start of transition, FDI inflows have been rising constantly but their magnitude and importance remain highly unequal

\footnotetext{
${ }^{9}$ Although this is not a new argument, it is still pressing and thus worth repeating. All the most widely used indicators of progress in reform for transition economies are retrospective, categorical and subjective in that they reflect Western economists' expert opinion. The point is that for, say, "rule of law," an expert's judgment is maybe necessary, while for, say, "number of key prices liberalized in a certain year" or "average level of tariffs" we must be able to have a measure that is not based on expert's judgment but on some harder evidence.
} 
across countries. In terms of cumulative FDI inflows, the considerable differences between CEEB and CIS countries (the FDI stock in the average CEEB country is larger than in the average CIS country) pale with respect to differences at the level of sub-groups. FDI is highly concentrated: the VISEGRAD and BUR (in this case, predominantly Russia) groups account for about 80 percent of the total stock of FDI in transition economies. If in turn these inflows are measured as a share of GDP, we find that this share is still higher in CEEB than in CIS countries. Interestingly, in the case of the ASIA countries, note that for Azerbaijan, the ratio of cumulative FDI inflows over GDP is above 90 percent and this ratio is also very high (about 45 percent) for Kazakhstan. For the Baltic countries, FDI over GDP ranges from about 38 percent for Estonia to about 20 percent in the case of Lithuania. The measure of net FDI inflows relative to countries GDP has been somewhat more dynamic since 1994 and hints that FDI is rapidly gaining importance not only in the Baltic countries' but also in Asia. For this latter group, the average rate of foreign direct investment went up from a mere 1 percent in 1994 to almost 35 percent of GDP in 1999. It should be noted that natural resources (oil and natural gas) are one of the most important determinants of such high FDI flows to ASIA (Kinoshita and Campos, 2003).

In sum, the performance of foreign trade in transition economies suggests the following developments. There was a decline and partial recovery pattern in the dynamics of foreign trade. Trade patterns have changed in that the share of industrial economies as export destination rose significantly. If the collapse of the CMEA was a major reason for the changing trade patterns in the initial stage of transition, the better export performance in western vis-à-vis eastern markets seems to dominate later on. The data suggest that there has been no tendency for transition economies to become less open, and in 1998 they were indeed relatively more open than under central planning. Examining PPP-adjusted measures of trade openness assert 1995 as bifurcation year: from 1995 onwards, openness increases for CEEB and decreases for the CIS countries. We also see that domestic reform as measured by a World Bank index of external liberalization has progressed faster in CEEB than in CIS. Finally, FDI inflows increased rapidly after 1994 but have been concentrated in a few transition countries.

\section{Empirical Results}

The objective of this section is to present the data, methods and our set of 
econometric results. We use standard regression techniques to investigate whether or not there are direct effects of actual GATT/WTO membership on four different outcome measures: trade openness, external liberalization (taken as one important aspect of domestic reform), per capita foreign direct investment inflows, and per capita real GDP growth. We investigate the effects of WTO membership within three different frameworks: (1) using standard OLS on cross-sectional data, (2) using panel data with country and year fixed-effects, and (3) using instrumentalvariable panel data estimation.

First, we evaluate the potential effect of GATT/WTO membership using crosssectional data with all variables averaged over the years 1990 to 1998 . Thus, we estimate the following:

$$
Y_{i}=\alpha+\beta W T O_{i}+\gamma X_{i}+e_{i}
$$

where $i$ denotes individual countries and $Y$ is one of the four different outcome measures (openness, reform, FDI or growth). WTO is a dummy variable that takes the value 1 if the country was a GATT/WTO member over 1990-1998, and zero otherwise (see Table 1 for the coding of this variable.) ${ }^{10}$

$\mathbf{X}$ is a vector of control variables and we set it as exactly the same for all four performance indicators. One issue we took into account in selecting the components of $\mathbf{X}$ was that we tried to include variables that are frequently found in the empirical literature on the transition from plan to market. We used the Campos and Coricelli (2002) review of the evidence as a guide. Thus, we decide to include the following variables in $\mathbf{X}$ : initial income (1989), average years of schooling, the fiscal balance, the abundance of natural resources, the size of the country's population and the average real per capita GDP growth among OECD countries. ${ }^{11}$

Secondly, we evaluate the effect of GATT/WTO membership using a fixedeffects estimator for the panel dimension of our data set. Note that in this case GATT/WTO membership is coded differently from above: WTO is a dummy variable that takes the value 1 for all years after the country becomes a GATT/ WTO member, and takes the value of zero for all years before. For illustration

\footnotetext{
${ }^{10}$ Some of the transition economies in our sample were members neither of GATT nor of the WTO so that the dummy variable for GATT/WTO membership takes the value of 1 if the country was a member of the WTO in 1998 and takes the value of zero if the country was not a member of the WTO in 1998. ${ }^{11}$ Data are from the GDN Database: http://www.unc.edu/ skolenik/GDN/
} 
purposes: from Table 1 we learn that Bulgaria became a member of the WTO in 1996. Thus, the $W T O$ variable for Poland is coded zero for all years up to 1995 and 1 for all years from 1996 onwards. The specification now is (where all else is the same but $t$ denotes year):

$$
Y_{i t}=\alpha+\beta W T O_{i t}+\gamma X_{i t}+e_{i t}
$$

Finally, in an attempt to minimize the possibility of endogeneity bias we also estimate equation (2) instrumenting WTO membership. Note that endogeneity may be a more severe issue for some outcome measures than others. In this light, we chose to use the following set of variables as instruments for WTO membership: initial income, population of the country, a dummy variable for involvement in armed conflict, a dummy for being a CIS country, and trade openness in 1989.

Before discussing the results, there a few observations to be made with respect to the raw data. The simple correlation coefficients for the cross-sectional data are as follows. Only two of them have values above 0.50 : the one between external liberalization and cumulative FDI inflows is 0.6 and the correlation between external liberalization and growth is 0.53 . Turning to the main variable of interest, GATT/WTO membership, the largest correlation is with per capita FDI inflows (0.44) followed by the one with the external reform index (0.39). For trade openness, the highest value is for the correlation with initial income while the second largest is (negative) with natural resources abundance. ${ }^{12}$ The reform index we use is positively correlated with economic growth and the second highest correlation is with OECD growth (0.53). Per capita FDI flows highest correlation is with external reform while its second highest correlation is with WTO membership. Finally, the highest correlation involving economic growth is with OECD growth and the second highest is the one with fiscal balance.

We now turn to the results. All tables are divided in three panels: Panel A shows results for OLS on cross-sectional data ("decadal" averages), Panel B shows the coefficient on the main variable of interest (WTO membership) for panel data with country fixed-effects, and Panel C has the same as Panel B but for IV estimation. Notice that, for space's sake, Panels B and C only contain the coefficient for WTO

\footnotetext{
${ }^{12}$ See Gylfason (2001) for a discussion of the relationship between openness and natural resources abundance.
} 
membership but the specification in both cases includes the variables shown in Panel A.

Table 2 has our results for the trade-to-GDP ratio which is taken from the latest Penn World Tables (version 6.1). Let us start with Panel A which has estimates for the cross-section of countries. It turns out that the coefficient on WTO

Table 2. The Effect of Membership in the WTO on Trade Openness (PWT 6.1)

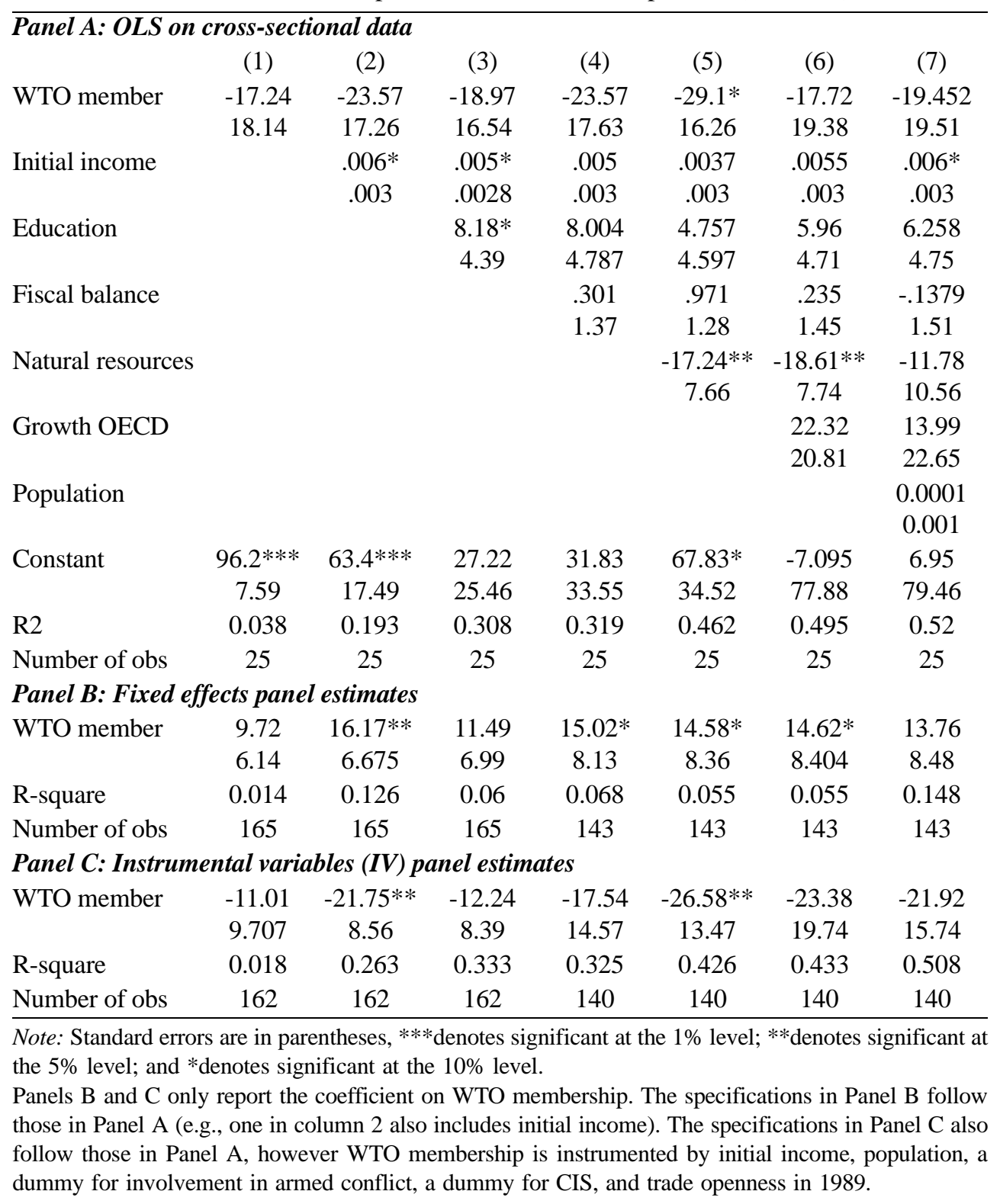


membership is always negative, including the only time it is statistically significant (column 5). On the other hand, natural resources abundance seem to be inversely related to trade openness, at least until we include a measure of country size (population).

Panel B has country fixed-effects panel estimates. We had hoped that the chances of capturing the 1995 bifurcation between CEEB and CIS in terms of trade openness would improve in this case. The results are a bit better than the ones we have for the cross-sectional data, but still far from satisfactory as the coefficient on WTO membership is always positive but statistically significant only in four (out of seven) specifications. Panel $\mathrm{C}$ has the instrumental-variable (IV) panel estimates. The results are worse than in the two other panels above as there is little evidence of an effect of GATT/WTO membership on the trade-toGDP ratio. In sum, the analysis so far suggests that there is little evidence in terms of a positive impact of GATT/WTO membership on trade openness during the transition from plan to market. Indeed, the few times the coefficient on WTO is statistically significant, it carries an unexpected sign.

Table 3 has our results for domestic reform efforts which are somewhat better than those for trade openness. The measure of reform we use a World Bank index of external liberalization discussed above which ranges from 0 to 1 where 0 represents "totally-unreformed" and 1 represents a "fully reformed" economy. Throughout Panel A, the coefficient on WTO membership is positive and statistically significant. The only other coefficient of note is that on natural resources which carries a negative sign suggesting that too much natural gas (and oil) seems to be detrimental for economic reform. The signs on most other coefficients are as expected, the one exception being the coefficients on education as it would be reasonable to expect that more human capital would be positively correlated with more intense reform efforts. One possible explanation is that there is too little variance as all these countries have similarly very high levels of human capital.

Panel B has fixed-effects panel estimates. The WTO membership coefficient is positive in every case and is always statistically significant at conventional levels. Although the size of the coefficient varies somewhat, it never changes sign. Panel $\mathrm{C}$ has the instrumental-variable (IV) panel estimates which confirm the expected positive impact of GATT/WTO membership on domestic reform efforts in terms of external liberalization. In sum, GATT/WTO membership seems to have a direct and positive impact on domestic reform efforts (yet, it is important to keep in mind 
Table 3. The Effect of Membership in the WTO on External Liberalization

\begin{tabular}{|c|c|c|c|c|c|c|c|}
\hline \multicolumn{8}{|c|}{ Panel A: OLS on cross-sectional data } \\
\hline & (1) & (2) & (3) & (4) & (5) & (6) & (7) \\
\hline WTO member & $\begin{array}{c}2.47 * * * * \\
(.734)\end{array}$ & $\begin{array}{c}2.28 * * * \\
(.735)\end{array}$ & $\begin{array}{c}2.29 * * * \\
(.759)\end{array}$ & $\begin{array}{c}2.06^{* * *} \\
(.787)\end{array}$ & $\begin{array}{l}1.75 * * \\
(.697)\end{array}$ & $\begin{array}{l}1.82 * * \\
(.704)\end{array}$ & $\begin{array}{l}1.67 * * \\
(.718)\end{array}$ \\
\hline Initial income & & $\begin{array}{l}.0002 \\
(.0002)\end{array}$ & $\begin{array}{c}0002 \\
(.0002)\end{array}$ & $\begin{array}{c}.0001 \\
(.0001)\end{array}$ & $\begin{array}{l}.00003 \\
(.0001)\end{array}$ & $\begin{array}{l}.00008 \\
(.0001)\end{array}$ & $\begin{array}{l}.00002 \\
(.0002)\end{array}$ \\
\hline Education & & & $\begin{array}{c}0002 \\
(.0002)\end{array}$ & $\begin{array}{l}-.0125 \\
(.2178)\end{array}$ & $\begin{array}{l}-.191 \\
(.201)\end{array}$ & $\begin{array}{c}-.1399 \\
(.21)\end{array}$ & $\begin{array}{l}-.1906 \\
(.216)\end{array}$ \\
\hline Fiscal balance & & & & $\begin{array}{l}.0281 \\
(.0691)\end{array}$ & $\begin{array}{l}.0702 \\
(.062)\end{array}$ & $\begin{array}{l}.0703 \\
(.063)\end{array}$ & $\begin{array}{l}.104 \\
(.071)\end{array}$ \\
\hline $\begin{array}{l}\text { Natural } \\
\text { resources }\end{array}$ & & & & & $\begin{array}{c}-.873 * * \\
(.324)\end{array}$ & $\begin{array}{c}-.7797 * * \\
(.342)\end{array}$ & $\begin{array}{c}-1.066^{* * *} \\
(.444)\end{array}$ \\
\hline Growth OECD & & & & & & $\begin{array}{c}22.57 \\
(25.35)\end{array}$ & $\begin{array}{c}19.32 \\
(25.54)\end{array}$ \\
\hline Population & & & & & & & $\begin{array}{l}.00001 \\
(.0001)\end{array}$ \\
\hline Constant & $\begin{array}{c}2.22 * * * * \\
(.305)\end{array}$ & $\begin{array}{l}1.306^{*} \\
(.742)\end{array}$ & $1.16(1.16)$ & $1.58(1.65)$ & $\begin{array}{c}3.59 * * \\
(1.63)\end{array}$ & $\begin{array}{l}-45.26 \\
(54.89)\end{array}$ & $\begin{array}{l}-37.45 \\
(55.39)\end{array}$ \\
\hline R-squared & 0.329 & 0.381 & 0.3819 & 0.354 & 0.533 & 0.554 & 0.578 \\
\hline Number of obs. & 25 & 25 & 25 & 25 & 25 & 25 & 25 \\
\hline \multicolumn{8}{|c|}{ Panel B: Fixed effects panel estimates } \\
\hline WTO member & $\begin{array}{c}3.99 * * * \\
(.607)\end{array}$ & $\begin{array}{c}3.83^{* * * *} \\
(.633)\end{array}$ & $\begin{array}{c}.802 * * * \\
(.288)\end{array}$ & $\begin{array}{l}.631 * * \\
(.296)\end{array}$ & $\begin{array}{l}.597 * * \\
(.297)\end{array}$ & $\begin{array}{l}.626 * * \\
(.295)\end{array}$ & $\begin{array}{l}.467^{*} \\
(.255)\end{array}$ \\
\hline R-squared & 0.226 & 0.254 & 0.61 & 0.575 & 0.579 & 0.593 & 0.01 \\
\hline Number of obs & 225 & 220 & 220 & 196 & 196 & 196 & 196 \\
\hline \multicolumn{8}{|c|}{ Panel C: Instrumental variables (IV) panel estimates } \\
\hline WTO member & $\begin{array}{c}5.12 * * * \\
(.657)\end{array}$ & $\begin{array}{c}4.91 * * * \\
(.675)\end{array}$ & $\begin{array}{c}5.13 * * * \\
(.699)\end{array}$ & $\begin{array}{c}4.91 * * * \\
(.739)\end{array}$ & $\begin{array}{c}4.15^{* * * *} \\
(.667)\end{array}$ & $\begin{array}{c}3.93 * * * \\
(1.05)\end{array}$ & $\begin{array}{c}4.01 * * * \\
(.894)\end{array}$ \\
\hline R-squared & 0.212 & 0.222 & 0.223 & 0.211 & 0.271 & 0.443 & 0.442 \\
\hline Number of obs & 211 & 211 & 211 & 187 & 187 & 187 & 187 \\
\hline
\end{tabular}

Note: Standard errors are in parentheses, $* * *$ denotes significant at the $1 \%$ level; ** denotes significant at the $5 \%$ level; and $*$ denotes significant at the $10 \%$ level.

Panels B and C only report the coefficient on WTO membership. The specifications in Panel B follow those in Panel A (e.g., one in column 2 also includes initial income). The specifications in Panel C also follow those in Panel A, however WTO membership is instrumented by initial income, population, a dummy for involvement in armed conflict, a dummy for CIS, and trade openness in 1989.

the caveat raised above about potential measurement error in this external reform variable).

Table 4 has our results with respect to cumulative per capita FDI inflows. Notice that in Panel A, the coefficient on WTO membership is always positive and it is statistically significant until column 5 (which adds OECD growth). For all 
Table 4. The Effect of Membership in the WTO on Per Capita FDI Inflows

\begin{tabular}{|c|c|c|c|c|c|c|c|}
\hline \multicolumn{8}{|c|}{ Panel A: OLS on cross-sectional data } \\
\hline & (1) & $(2)$ & (3) & (4) & $(5)$ & $(6)$ & (7) \\
\hline \multirow{2}{*}{ WTO member } & $311 * * *$ & $253 * * *$ & $262 * * *$ & $236.1 * *$ & $219.7 * *$ & 221.367 & 186.25 \\
\hline & 100.55 & 87.49 & 89.12 & 84.579 & 85.839 & 137.88 & 142.87 \\
\hline \multirow{2}{*}{ Initial income } & & $.048 * * *$ & $.046^{* * *}$ & $.0363 * *$ & $.033 * *$ & $.033 *$ & $.0375 * *$ \\
\hline & & .0153 & .0157 & .0149 & .01528 & .0169 & .017 \\
\hline \multirow{2}{*}{ Education } & & & 18.75 & 13.187 & 4.9868 & 4.955 & 9.867 \\
\hline & & & 23.83 & 22.94 & 24.204 & 24.95 & 25.514 \\
\hline \multirow{2}{*}{ Fiscal balance } & & & & .876 & \multirow{2}{*}{2.747 .378} & 2.644 & 2.43 \\
\hline & & & & 7.17 & & 9.935 & 9.957 \\
\hline \multirow{2}{*}{$\begin{array}{l}\text { Natural } \\
\text { resources }\end{array}$} & & & & & -40.95 & -40.978 & -7.2285 \\
\hline & & & & & 39.28 & 40.38 & 53.503 \\
\hline \multirow{2}{*}{ Growth OECD } & & & & & & 7.9509 & -244.46 \\
\hline & & & & & & 525.85 & 588.32 \\
\hline \multirow{2}{*}{ Population } & & & & & & & .00001 \\
\hline & & & & & & & $(.0001)$ \\
\hline \multirow{2}{*}{ Constant } & $86.73 *$ & $-170.17 *$ & $-252.74 *$ & -188.29 & -93.63 & -112.87 & 418.21 \\
\hline & 42.806 & 89.64 & 138.504 & 178.35 & 199.79 & 1289.35 & 1404.37 \\
\hline R-squared & 0.295 & 0.513 & 0.527 & 0.525 & 0.551 & 0.551 & 0.574 \\
\hline Number of obs & 25 & 25 & 25 & 25 & 25 & 25 & 25 \\
\hline \multicolumn{8}{|c|}{ Panel B: Fixed effects panel estimates } \\
\hline WTO member & $\begin{array}{l}294 * * * \\
(70.21)\end{array}$ & $\begin{array}{c}79.62 \\
(64.13)\end{array}$ & $\begin{array}{c}-58.16 \\
(52.07)\end{array}$ & $\begin{array}{l}-33.32 \\
(51.77)\end{array}$ & $\begin{array}{l}-48.41 \\
(51.89)\end{array}$ & $\begin{array}{l}-49.33 \\
(52.07)\end{array}$ & $\begin{array}{c}-64.24 \\
(51.24)\end{array}$ \\
\hline R-squared & 0.209 & 0.348 & 0.402 & 0.382 & 0.378 & 0.372 & 0.373 \\
\hline Number of obs & 188 & 188 & 188 & 164 & 164 & 164 & 164 \\
\hline \multicolumn{8}{|c|}{ Panel C: Instrumental variables (IV) panel estimates } \\
\hline \multirow{2}{*}{ WTO member } & $407 * * *$ & $301 * * *$ & $330 * * *$ & $283 * *$ & $261.8 * *$ & $308 * * *$ & $313 * * *$ \\
\hline & $(71.708)$ & $(68.72)$ & $(69.11)$ & $(122.94)$ & $(120.67)$ & $(112.65)$ & $(113.1)$ \\
\hline R-squared & 0.208 & 0.322 & 0.331 & 0.339 & 0.358 & 0.408 & 0.417 \\
\hline Number of obs & 187 & 187 & 187 & 163 & 163 & 163 & 163 \\
\hline
\end{tabular}

Note: Standard errors are in parentheses, $* * *$ denotes significant at the $1 \%$ level; $* *$ denotes significant at the $5 \%$ level; and $*$ denotes significant at the $10 \%$ level.

Panels B and C only report the coefficient on WTO membership. The specifications in Panel B follow those in Panel A (e.g., one in column 2 also includes initial income). The specifications in Panel C also follow those in Panel A, however WTO membership is instrumented by initial income, population, a dummy for involvement in armed conflict, a dummy for CIS, and trade openness in 1989.

other variables, there is very little to note as none of the coefficients is statistically significant at conventional levels. The exception is initial income that turns out to carry a positive sign and is statistically significant thus suggesting that countries that were richer at the outset of the transition seem to have been more successful in attracting FDI.

Panel B of Table 4 shows our fixed-effects panel estimates for GATT/WTO 
membership. Unfortunately, the coefficient on WTO membership is only significant once. Panel $\mathrm{C}$ has the instrumental-variable (IV) panel estimates which shows that a positive effect of WTO membership of FDI inflows. In a nutshell, with respect to foreign direct investment inflows, actual WTO membership seems to have had no robust direct impact during the transition from plan to market.

Finally, Table 5 has our last set of results, those for real per capita GDP growth.

Table 5. The Effect of Membership in the WTO on Per Capita Real GDP Growth

\begin{tabular}{|c|c|c|c|c|c|c|c|}
\hline \multicolumn{8}{|c|}{ Panel A: OLS on cross-sectional data } \\
\hline & (1) & (2) & (3) & (4) & (5) & (6) & (7) \\
\hline \multirow[t]{2}{*}{ WTO member } & $6.15^{* * *}$ & $5.81 * * *$ & $6.08 * * *$ & $6.76 * * *$ & $6.48 * * *$ & $7.02 * * *$ & $6.47 * * *$ \\
\hline & 1.65 & 1.68 & 1.68 & 2.03 & 2.09 & 1.75 & 1.714 \\
\hline \multirow[t]{2}{*}{ Initial income } & & .0003 & .0003 & .0002 & .0001 & .0005 & .0002 \\
\hline & & .0003 & .0003 & .0004 & .0004 & .0003 & .0004 \\
\hline \multirow[t]{2}{*}{ Education } & & & .508 & .398 & .237 & .666 & .471 \\
\hline & & & .445 & .562 & .601 & .524 & .516 \\
\hline \multirow[t]{2}{*}{ Fiscal balance } & & & & .073 & .111 & .111 & .241 \\
\hline & & & & .178 & .186 & .156 & .169 \\
\hline \multicolumn{2}{|l|}{ Natural } & & & & -.7761 & .0002 & -1.101 \\
\hline \multicolumn{2}{|l|}{ resources } & & & & .968 & .853 & 1.06 \\
\hline \multirow{2}{*}{\multicolumn{2}{|c|}{ Growth OECD }} & & & & & $188 * * *$ & $176 * * *$ \\
\hline & & & & & & 63.18 & 60.96 \\
\hline \multicolumn{2}{|l|}{ Population } & & & & & & $\begin{array}{l}.00001 \\
(.0001)\end{array}$ \\
\hline \multirow[t]{2}{*}{ Constant } & $-5.56 * * *$ & $-7.23 * * *$ & $-9.47 * * *$ & $-9.03 * *$ & -7.23 & $-415 * * *$ & $-386 * * *$ \\
\hline & .687 & 1.69 & 2.58 & 4.26 & 4.87 & 136.8 & 132.2 \\
\hline R-squared & 0.3760 & 0.4068 & 0.4417 & 0.4432 & 0.4615 & 0.6401 & 0.6886 \\
\hline Number of obs & 25 & 25 & 25 & 25 & 25 & 25 & 25 \\
\hline \multicolumn{8}{|c|}{ Panel B: Fixed effects panel estimates } \\
\hline \multirow[t]{2}{*}{ WTO member } & $6.85 * * *$ & 4.611 & -4.11 & -5.46 & $-6.078 *$ & -5.72 & -6.218 \\
\hline & 3.31 & 3.52 & 3.33 & 3.51 & 3.54 & 3.49 & 3.49 \\
\hline R-squared & 0.0649 & 0.0891 & 0.1816 & 0.2256 & 0.2229 & 0.2535 & 0.2535 \\
\hline Number of obs & 225 & 220 & 220 & 196 & 196 & 196 & 196 \\
\hline \multicolumn{8}{|c|}{ Panel C: Instrumental variables (IV) panel estimates } \\
\hline \multirow[t]{2}{*}{ WTO member } & $14.62 * * *$ & $14.4 * * *$ & $15.4 * * *$ & $14.4^{* * *}$ & $12.1 * * *$ & $11.2 * * *$ & $10.4^{* * *}$ \\
\hline & 2.92 & 3.05 & 3.14 & 3.41 & 3.29 & 3.11 & 3.06 \\
\hline R-squared & 0.0694 & 0.0702 & 0.0727 & 0.1652 & 0.1860 & 0.2804 & 0.3084 \\
\hline Number of obs & 211 & 211 & 211 & 187 & 187 & 187 & 187 \\
\hline \multicolumn{8}{|c|}{$\begin{array}{l}\text { Note: Standard errors are in parentheses, } * * * \text { denotes significant at the } 1 \% \text { level; } * * \text { denotes significant at } \\
\text { the } 5 \% \text { level; and } * \text { denotes significant at the } 10 \% \text { level. }\end{array}$} \\
\hline
\end{tabular}


Note that in panel A, the coefficient on GATT/WTO membership is always positive and it is also always statistically significant. The other result worth mentioning is the only other variable that seems to have an effect on economic growth seems to be the growth rate of the OECD countries. There is little to say for the other variables as none is statistically significant at conventional levels. Panel B has fixed-effects panel estimates and here is where these positive results for WTO membership ran into problems as it is shown that the coefficient is seldom statistically significant and in one opportunity in which it is statistically significant, it carries an unexpected negative sign.

Panel $\mathrm{C}$ has instrumental-variable (IV) panel estimates. The results are better than in the two previous panels. The coefficient on WTO membership is always significant and in all specifications, statistically significant. Using the same reasoning as before, we conclude that the evidence of a positive effect of actual GATT/WTO on per capita GDP growth can not be considered to be strong, particularly in light of our country fixed-effects estimates (Panel B).

\section{Conclusions}

This paper reports some initial results towards an understanding of the relationship between GATT/WTO membership and the process of transition from centrally planned to market economy in Central Europe and in the former Soviet Union. The point of departure was the observation that low income transition economies which have shown modest amounts of trade reorientation as well as less intensive reform efforts in terms of external liberalization tend not to be members of the WTO, while those transition countries that are members of the WTO tend to have higher income and seem to have experienced more trade reorientation and more extensive reforms. We also noted that the transition economies of Central and Eastern Europe joined GATT/WTO at different points in time. Against this backdrop, we consider the possibility that WTO membership would be beneficial to transition economies for some of the reasons that are often associated with EU membership, in particular, tying reformers' hands.

Using panel data for 25 transition economies between 1990 and 1998, we find that WTO membership had little impact on trade openness, FDI and growth, but a positive effect on domestic reform (external liberalization).

Unfortunately, we can not yet distinguish whether this effect is real or due to the poor measurement of reform. In this paper, we draw on a measure of external 
liberalization (reform) which is used widely in the transition literature. This measure is constructed retrospectively and is influenced by judgements of Western experts, which could in turn be influenced by the accession of some countries to the WTO. In other words, there is a possibility that the standard measure of external liberalization used in the transition literature also takes into account (implicitly) whether a country is a WTO member. If this is the case, the results presented above are weakened and, in the limit, they would agree fully with Rose's (2003) for larger samples on the very limited impact of GATT/WTO membership.

This leaves us with two main directions for future research. The first is the construction of objective and more satisfactory measures of reform, in this case, of external liberalization. It is important to stress that this is a crucial step as only it will allow us to confidently separate the effect of WTO membership from the standard measure of external liberalization in the transition literature. The second direction for future research would be to investigate fully the structure of the proposed effects, more specifically, to try to distinguish between direct and indirect effects. Notice that our results at least hint at which relationship can be particularly worth pursuing. For instance, one may speculate that WTO membership fosters trade openness and openness in turn positively affects economic growth. Although there is some evidence on the latter (Frankel and Romer, 1999), we find little support in this paper for the former. Alternatively, one can conjecture that WTO membership fosters FDI and that FDI fosters growth. Again there is some evidence on the latter (Campos and Kinoshita, 2002), but we find very little support for the former. One could also conjecture that WTO membership fosters domestic reforms which in turn affect FDI and openness (which, by their turn, may influence economic growth). In this paper, we present empirical evidence that supports the notion that actual WTO membership fosters domestic reforms. Investigating this latter set of relationships, once better measures of reform are available, seems the best way forward.

\section{Acknowledgments}

I thank Tony Addison, Kym Anderson, Betina Dimaran, Yuko Kinoshita, Sam Laird, Jong Eun Lee, Mansoob Murshed, Howard Shatz, two anonymous referees and workshop participants at WIDER (World Institute for Development Economics Research of the United Nations University, Helsinki) for helpful 
comments on previous versions of this paper. Special thanks go to Basudeb GuhaKhasnobis for the invitation to think about these issues, without which this paper would not have been written. All remaining errors are, of course, my own.

Received 7 August 2003, Accepted 22 March 2004

\section{References}

Bachetta, Marc and Zdenek, Drabek (2002), "Effects of WTO Accession on PolicyMaking in Sovereign States: Preliminary Lessons from the Recent Experience of Transition Countries," Geneve, WTO Working Paper 2002-02.

Baldwin, R. E. (1994), Towards an Integrated Europe, London, CEPR.

Belkindas, M.V. and Ivanova, O.V. (1995), Foreign Trade Statistics in the USSR and Successor States, Washington DC: World Bank.

Berglof, Eric and Roland, Gerard (1997), "The EU as an Outside Anchor for Transition Reforms," Stockholm, SITE Working Paper No. 132.

Brenton, P. and Gros, D. (1997), "Trade Reorientation and Recovery in Transition Economies," Oxford Review of Economic Policy, 13 (2).

Campos, Nauro and Yuko Kinoshita (2002), "Foreign Direct Investment as Technology Transferred: Some Panel Evidence from the Transition Economies," Manchester School, 70 (3): 398-419.

Campos, Nauro and Coricelli, Fabrizio (2002), "Growth in Transition: What We Know, What We Dont, and What We Should," Journal of Economic Literature, 40 (3).

De Melo, M., Denizer, C., Gelb, A. and S. Tenev (1997), "Circumstance and Choice: The Role of Initial Conditions and Policies in Transition Economies," World Bank WPS 1866.

Djankov, Simeon and Peter Murrell (2002), "Enterprise Restructuring in Transition: A Quantitative Survey," Journal of Economic Literature, 40 (3).

European Bank for Reconstruction and Development, various years. Transition Report, London: European Bank for Reconstruction and Development [EBRD].

Ericsson, Richard (1991), "The Classical Soviet-Type Economy: Nature of the System and Implications for Reform," Journal of Economic Perspectives 5:4, pp. 11-28.

Frankel, J. and D. Romer (1999), "Does Trade Cause Growth?" American Economic Review 89 (3): 379-399.

Gylfason, Thorvaldur (2001), "Natural Resources, Education, and Economic Development," European Economic Review 45 (4-6):847-859.

Havrylyshyn, O. and Al-Atrash, H., "Opening Up and Geographic Diversification of Trade in Transition Economies," IMF WP/98/22, February 1998.

Heston, Alan, Robert Summers and Bettina Aten, "Penn World Tables Version 6.1," University of Pennsylvania (CICUP), October 2002 (http://pwt.econ.upenn.edu/).

Holmes, Peter (2001), "The WTO and the EU: Some Constitutional Comparisons," 
Economics Department, University of Sussex, Discussion Paper No. 78.

Holmes, Peter and Iacovone, Leonardo (2001), "Risk Rationality and Regulation in the EU and the WTO," Economics Department, University of Sussex, mimeo.

IMF, Direction of Trade Statistics Database, various issues.

Kaminski, B., "How Accession to the European Union has Affected External Trade and Foreign Direct Investment in Central European Economies," World Bank, WPS 2578, April 2001.

Kaminski, B., Wang, Z. K. and Winters (1996), A., Foreign Trade in the Transition: The International Environment and Domestic Policy, World Bank.

Kinoshita, Yuko and Campos, Nauro F. (2003), "Why Does FDI Go Where It Goes? New Evidence from the Transition Economies," IMF- Univ. of Newcastle, mimeo.

Kornai, János (1992), The Socialist System: The Political Economy of Communism, Princeton: Princeton University Press.

Levinsohn, James (1993), “Testing the imports-as-market-discipline hypothesis,” Journal of International Economics 35 (1-2): 1-22.

Michalopoulos, C. (1998), "WTO Accession for Countries in Transition," World Bank, WPS 1934.

Michalopoulos, C. and Tarr, D. (1996), Trade Performance and Policy in the New Independent States, Directions in Development, World Bank.

Maurel, M. and Cheikbossian, G. (1997), "The New Geography of East European Trade", London: CEPR Discussion Paper No. 1580.

Ofer, Gur (1987), "Soviet Economic Growth: 1928-85," Journal of Economic Literature 25: 4, pp. 1767-1833.

Rose, Andrew, "Do WTO Members Have More Liberal Trade Policy?" Journal of International Economics, forthcoming.

Staiger, Robert and Guido Tabellini (1987), "Discretionary Trade Policy and Excessive Protection," American Economic Review 77, 823-837.

Staiger, Robert and Guido Tabellini (1999), "Do GATT Rules Help Governments Make Domestic Committments?" Economics \& Politics 11 (2), 109-144.

Stiglitz, Joseph. 1994. Whither Socialism? Cambridge: MIT Press. 